\title{
La conquista de los elementos: evolución de la vanguardia dominicana en sus prosas (del Postumismo a Manuel del Cabral)
}

\section{TANTEOS: DANZAS TERRESTRES, PIRUETAS AZULES EN EL CIELO}

Cuenta García Márquez, en su reciente «El mismo cuento distinto» ${ }^{1}$, que anduvo cerca de medio siglo en busca de un relato de Simenon que leyó en su juventud y dejó en él una huella profunda. Durante cuarenta y cuatro años, el narrador colombiano siguió todo tipo de pistas en pos del comisario Maigret, quien a su vez seguía eterna y pacientemente (tal vez esperando a su lector perdido) a un joven polaco elusivo que se demoraba por las calles y los muelles parisinos. Al final, se produjo el doble encuentro: Maigret detuvo al sospechoso, y García Márquez pudo una vez más ser testigo de aquella persecución y captura. La danza había terminado felizmente, el círculo se había cerrado.

La «danza» de Ias vanguardias literarias en la República Dominicana comienza, según obra en las crónicas ${ }^{2}$, en la primavera de $1921^{3}$, cuando un grupo de escritores e intelectuales dominicanos lanza el Manifiesto postumista desde lo que bautizaron como «Colina

'Fechado en Cartagena de Indias en 1993, sirve de introducción al volumen $\mathrm{O}$ de la colección en que Tusquets viene publicando desde entonces todas las novelas de George Simenon protagonizadas por el inspector Maigret, y precede al cuento aEl hombre de la calle», escrito por Simenon en Nieul-sur-Mer en 1939 (Barcelona: Tusquets Editores, 1994).

2 Ver especialmente: Müller-Bergh, Klaus: «Indagación del vanguardismo en las Antillas: Cuba, Puerto Rico, Santo Domingo, Haití», en: Burgos, Femando (coord.): Prosa hispánica de vanguardia. Madrid: Orígenes, 1986, págs. 55-76. Henríquez Ureña, Max: Panorama histórico de la literatura dominicana. Santo Domingo, R.D.: Editorial Librería Dominicana, 1965, págs. 260-270 (primer tomo).

${ }^{3}$ Según Müller-Bergh, «probablemente» fue el 18 de marzo de dicho año.

Anales de Literatura Hispanoamericana, n. ${ }^{\circ} 26$ II. Servicio de Publicaciones, UCM. Madrid, 1997 
Sacra» ${ }^{4}$. La República Dominicana se encuentra entonces en su quinto año de ocupación por los Estados Unidos (finalizará tres años después, cuando poco a poco se vaya irguiendo la ominosa sombra de Rafael Leónidas Trujillo), y viene de una historia vertiginosa que la llevó de la dominación española a la francesa, para luego ser ocupada por las tropas haitianas. El Manifiesto postumista ${ }^{5}$ se inscribe dentro de una resistencia civil y «educada» a la ocupación, y expone un deseo ferviente de auténtica identidad nacional en la cultura dominicana ( arte autóctono», como se reivindica en el apartado $\mathrm{C}$ del Manifiesto). El texto estandarte de los postumistas está en la más pura tradición de los manjfiestos de las primeras décadas de nuestro siglo: en él parece recogerse, de una forma rotunda y segura de sí, la creación de un arte nuevo, de una visión distinta de las cosas que rompe con lo inmediatamente anterior ( «Rubén Darío ha muerto», clama el apartado J) para crear sin ataduras. Sin embargo, y como ya han apuntado otros críticos (Müller-Bergh, Sáinz de Medrano), la lectura del Manifiesto nos sume en la perplejidad, pues en su afán de desligarse de todo, arremete también contra los movimientos vanguardistas contemporáneos. Así, en el apartado J leemos:

Reaccionamos también contra los ultraístas, futuristas y creacionistas que pretenden en 'acrobaciáa azul' y sobre grupa de aeroplanos ir a conquistar un más allá desconocido en las nubes.

Previamente, en el apartado E, habían declarado su antifuturismo («Seremos humanamente eternistas») y su adhesión a modelos clásicos e «inmortales» de la cultura universal («Para nuestra ruta no olvidaremos el Corán y la Divina Comedia, la Biblia y el Quijote.»). Aún más sorprendente es el apartado I: «Sofrenaremos la imaginación con las bridas en tensión de los sentidos». Y el M: «Serenidad, mucha serenidad (...)». Todo parece contradecir en su esencia al espíritu de la vanguardia. No son de extrañar las duras palabras de Enrique Anderson Imbert ${ }^{6}$, quien concluye que los postumistas «carecían del espíritu travieso, juguetón e irreverente de los vanguardistas». Imputación que puede parecernos injusta si acepta-

4 «Una pequeña elevación urbana (...) situada en Villa Francisca, modema barriada de la ciudad de Santo Domingo (Max Henríquez Ureña, op. cit., pág. 265).

${ }^{5}$ El que tenemos a nuestra disposición es el reproducido (págs. 109-111) por Nelson Osorio T. en Manifiestos, proclamas y polémicas de la vanguardia literaria hispanoamericana (Caracas: Biblioteca Ayacucho, 1988), libro muy útil, a mi entender, más por el material seleccionado que por su discutible estudio inicial. A su vez, Osorio lo reproduce de otra antología, en ese juego de cajas chinas que nos da idea de la lejanía de aquellos años en Colina Sacra (es complicado acceder a los documentos originales).

6n su Hisioria de la literafma hispanoamericana (México: Fondo de Cultura Económica, 1954), tomo II, págs. 36-37. 
mos que, en el fondo, nunca pretendieron adherirse a las vanguardias. Así nos lo hizo ver el autor sin duda más brillante que salió del postumismo, Domingo Moreno Jimenes (n. 1894) que escribía en 1947: «El vanguardismo es una actitud del pensamiento, mientras que el postumismo es un estado del espíritu. Puede abarcar lo actual, lo anterior o lo posterior» ${ }^{7}$.

En una línea más esteticista sobrevuelan los ocupados cielos del país antillano las propuestas vagamente esbozadas por Otilio Vigil Díaz (18801961) en su movimiento de nombre inspirado en el de un aviador francés: el veedrinismo (según Max Henríquez Ureña), vedrinismo (según Nelson Osorio T.) o vendrinismo (según Müller-Bergh), que de tal manera es escurridizo y mudable dicho movimiento, nacido al fin y al cabo al amor de piruetas aéreas ${ }^{8}$. El vedrinismo, como se ve, se sitúa frente a las directrices postumistas, pues Vigil Díaz monta abiertamente «sobre grupa de aeroplanos» y pretende «acrobacias azules». Ni Max Henríquez Ureña ni Nelson Osorio T. ${ }^{9}$ consideran al vedrinismo vanguardista; sería más bien, para ambos, un movimiento epigonal dentro del modernismo, que además no creó una escuela definida a su alrededor. De hecho, al leer las «Palabras preliminares» de Vigil Díaz a su poemario Galeras de Pafos (1921) ${ }^{10}$, descubrimos no ya tan sólo a un modernista tardío -el texto está empedrado de Romas y Cartagos, Athenas (sic) y Bizancios, París/Francia/Sena/ Baudelaire- sino también a un romántico de manual, emborrachado de palabras/música: «Siempre me he empeñado en no perder el pensamiento y la palabra que me da con lealtad y exactitud la medida de mi sensibilidad, mi música íntima, la conservación intacta de mi yo; y por lo demás y los más, que derrame su veneno el crótalo y su baba el caracol» (los subrayados son míos). Resulta, cuanto menos, conmovedor, leer cómo pretende rechazar cierta retórica altisonante de los modernistas cayendo de pleno en ella, así el insecto que huye de la araña para caer sin remedio en su tela:

¿'Galeras de Pafos"?... Afroditas, Melitas, Lesbias, Hetairas y Pallakas. Incubos y Súcubos. Sadismos y Masoquismos. Sátiros y Bacantes coronados de pámpanos. Eurritmicos efebos deshojando

'Página 25 de su interesante opúsculo Burbujas en el vaso de una vida trevé, publicado en Ciudad Trujillo (hoy Santo Domingo) en 1948.

${ }^{8} \ll(. .$.$) tomó su nombre del aviador francés Jules Vendrines (1881-1919), piloto de$ la Segunda Guerra Mundial (sic, obviamente de la primera contienda), creador de las peligrosas piruetas aéreas del 'looping the loop', quien adquirió fama en 1911 en su famoso vuelo París-Madrid (...)». (Manuel Rueda y Lupo Hernández Rueda: Antología de la poesía dominicana contemporánea (19/2-1962). Santiago de los Caballeros, 1972. Según son citados por Müller-Bergh, pág. 64).

${ }^{9}$ Max Henríquez Ureña, op. cit., págs. 266-269. Nelson Osotio T., op. cit., nota 24, pag. XX.

10 En Nelson Osorio T., op. cit., págs. 86-87. 
rosas. Lechos de sándalo y marfil. Simiente. Palomas blancas y vasos de perfumes. Turíbulos de crepitantes y embriagadoras sandáracas. [...] Pues nada de eso; el título de este libro nada tiene que ver con el alma de este libro, que es casi inofensiva, transparente y sencilla como una campiña; es simplemente el cumplimiento de un canon parnasiano: todo título debe ser bello, poco importa que no diga nada. (subrayados míos)

La negación rotunda («nada de eso») suena a hueca y a falsa, Vigil Díaz se deleita en la enumeración primera. En su libro Orégano: Cuentos criollos ", descubrimos a un narrador con una casi enfermiza "voluntad de estilo» que hace de su prosa un continuo repertorio de musicalidades y sensorialidad a flor de piel, dentro de unas descripciones marcadamente modernistas en muchas ocasiones (los valles son «canoros», los insectos «noctívagos», las noches y los silencios casi siempre «trágicos»), naturalistas en otras (un soldado herido en una refriega tenía «un brazo desflecado y la panza aventada como la de un mero, por la peritonitis progresiva y fulminante»-pág. 25 , un callejón «estrecho, húmedo y hediondo a amoníaco y a sulfatos intestinales»-pág. 34) y, casi siempre irónicas y distanciadoramente humorísticas, lo cual redime y da sentido a prosas a ratos demasiado pirotécnicas, y establece un puente hacia la prosa vanguardista («miró agresivamente al Secretario, abriendo y cerrando tres veces de seguido el ojo izquierdo, que era su tic criminal, francamente lambrosiano...»-pág. 56). En conjunto, coincidimos con la aseveración de MüllerBergh, quien afirma que «un vendrín no hace vanguardia» ${ }^{12}$, aunque debemos matizar que se encuentra ya en camino gracias a la inserción liberadora de un nuevo humorismo dentro de las galas postmodernistas ${ }^{13}$.

Tras postumistas y vedrinistas, los espacios literarios dominicanos se vacían de tentativas vanguardistas y las historias literarias nos las devuelven veinte años más tarde, cuando un nuevo grupo de poetas se une «alrededor de La poesía sorprendida de octubre de 1943 a mayo de 1947» (Müller-Bergh, op. cit., pág. 67) en un proyecto renovador mucho más ambicioso que se opone firmemente a lo que el escritor español Eugenio Fernández Granell, exiliado durante unos años en la República

11 Ciudad Trujillo, R.D.: Impresora Dominicana, 1949.

${ }^{12}$ Op cit. pág. 64

1.3 «'En el arte nuevo de las vanguardias', si la literatura en general pierde su seriedad. los humoristas, conscientes de que ha llegado su hora, la ganan, $y$, en nombre de todos. Ramón proclama 'la gravedad e importancia del humorismo'. El humorismo no es ya una forma de cscapar de los problemas de la vida, sino, al contrario, la mejor manera de enfrentarse a ellos: "la actitud más cierta ante la efimeridad de la vida es el humor»'. (De la antologfa elaborada por Ramón Buckley y John Crispin, Los vanguardistas españoles (1925-1935). Madrid: Alianza Editorial, 1973, pág. 265). 
Dominicana tras la Guerra Civil española, llamó la «trujillización» de la cultura (Müller-Bergh, pág. 67).

\section{REFLEXIÓN Y CONTRA-REFLEXIÓN}

\section{Reflexión}

Hasta aquí lo que nos cuentan tanto la historiografía literaria como nuestras lecturas. Pocas y descorazonadoras pistas para llevar a cabo nuestra indagación, a lo que hay que unir la dificultad de acceder a los textos y lo (a veces) confundido y confundidor de los manuales bibliográficos especializados en el tema de las vanguardias hispanoamericanas cuando aportan datos sobre la República Dominicana ${ }^{14}$. El trayecto de las vanguardias dominicanas se nos presenta, así, como un camino truncado: de las tímidas tentativas de los postumistas y de los vedrinistas pasamos, en un lapso de tiempo de unos veinte años, a unas nuevas tentativas, más firmes, sin duda, pero tentativas al fin y al cabo: las de los miembros de La poesía sorprendida. El fluir vital de las vanguardias - Guillermo de Torre había escrito que «al tiempo de las búsquedas había de seguir el de las decantaciones» ${ }^{15}$, y Octavio Paz hablaba de un tránsito que llevaba del «inventar» de los años veinte al «explorar» de la nueva vanguardia surgida tras la Segunda Guerra Mundial 16 dentro de las letras dominicanas, o al menos eso parecían indicar todas las bibliografías vigentes (tanto las generales como las más especializadas) que como mucho tocan el tema como si de una mera anécdota sin importancia en las letras del país antillano se tratase.

Sería fácil, aunque simplista, justificar dicha visión panorámica. Tres argumentos apoyarían la aparente realidad señalada:

A.- Por un lado, las vanguardias literarias tienden con frecuencia a ser consideradas como un fenómeno que tiene su raíz, cuando no su pleno

1. Manejamos dos recientes: Forster, Merlin H., y K. David Jackson (comp.): Vanguardism in Latin American Literature. An annotated Bibliographical Guide. Wesport, CT.: Greenwood Press, 1990. Wentzlaff-Eggebert: Las literaturas hispánicas de vanguardia. Orientación bibliográfica. Frankfurt am Main: Vervuert Verlag, 1991. En este último se llega a mencionar La novela del indio Tupi (sic), del español Fennández Granell, como obra destacable dentro de la vanguardia domincana. Dicha novela ( $\mathrm{La}$ novela del indio Tupinamba. Madrid: Fundamentos, 1982, 1 edic. española), es una alucinante narración surrealista y esperpéntica de nuestra guerra civil.

15 En: Historia de las literaturas de vanguardia. Madrid: Ediciones Guadarrama, 1971 (págs, 28-29, vol. 1).

16. Octavio Paz. Los hijos del limo. Det romanticismo a la vanguardia. Barcelona: Seix Barral, 1986 (pág. 209). 
desarrollo, en lo urbano y, más específicamente, en «la moderna metrópoli» surgida al final de la Primera Guerra Mundial ${ }^{17}$. Ello presupone la existencia de una realidad urbana, de una gran ciudad que actúe como vertebración y, sobre todo, inspiración, de los movimientos vanguardistas. No en vano, la ciudad sugiere movimiento, cambio incesante, mientras que el medio rural evoca quietismo y permanencia, y tales nociones parecen contradictorias con respecto a una cierta ( $y$, nos apresuramos a señalar, estrecha) visión de lo que son las vanguardias. Pues bien: la República Dominicana de la era de las vanguardias era, en palabras del narrador Juan Bosch, «una sociedad eminentemente rural» 18 . No había nada ni remotamente parecido a nuestro concepto de metrópoli: «Las ciudades del país estaban, con la excepción de San Pedro de Macorís, transidas de ruralidad. Todavía en los primeros años del gobierno de Trujillo la población de la capital se levantaba a las 5 de la mañana, hábito muy campesino, muy rural, y naturalmente, se acostaba temprano» ${ }^{19}$. ¿Era posible que de tal sociedad surgiese un movimiento vanguardista?

B.- Una de las características más comúnmente aceptadas como definidora de la literatura y el arte en general de las vanguardias es su internacionalismo, su continuo transgredir las fronteras no tan sólo de la imaginación, sino también las geográficas. Se habla de un arte nuevo de ámbito universal, y la noción nacionalista resulta antitética y ajena, limitadora, estéril. La República Dominicana se encuentra, cuando estallan por doquier los aires nuevos en occidente, ocupada por tropas extranjeras, y devendrá luego en un país aislado y cerrado por la dictadura de Trujillo (1930-1961). No es pues de extrañar que en su manifiesto insignia, los postumistas afirmen con orgullo: "Hemos levantado la estatua con el barro grotesco de nuestra América» (apartado B), y arranquen con un contundente «la América debe superar a la Europa». Este explícito rechazo de los cánones culturales de allende los mares contradice una universalidad plena del arte, de la literatura. Su ideal es distinto: «nos queda mucho barro, mucho barro que es nuestro ideal universalizado» (apartado B). ¿No nos encontraremos, una vez más, ante localismos insalvables que difícilmente podrán desembocar en vanguardia? ${ }^{20}$.

C.- Estas líneas tienen como objeto más directo la prosa de vanguardia en la República Dominicana. Sin embargo, para llegar a la prosa creativa se

17 Ver Buckley y Crispin, op. cit., págs. 177-178.

18 Página VIII del prólogo a la colección de cuentos del domicano Virgilio Grullón De miños. hombres y fanlasmas. Santo Domingo, R.D.: Biblioteca Taller, 1982 (2" edic.. la 1 es es de 1981 ).

1\% Ídem, pág. XI.

${ }^{20}$ Según Müller-Bergh, «los postumistas se sienten básicamente nacionales» y siguen acentuando «la nola personalista, local». (Müller-Bergh, op. (it., pág. 67). 
ha de pasar por los tanteos previos que encierran manifiestos y textos en verso. Dice Guillermo de Torre: «la preponderancia de lo poético corresponde al período de pubertad en los seres y en la literatura». Y, líneas antes: «a partir de cierta fecha, cuando el ímpetu innovador de las vanguardias se debilitó, las innovaciones formales y temáticas se acusaron más visiblemente en el plano novelesco $\gg{ }^{2 !}$. ¿Cómo llegar a una prosa vanguardista en un país donde apenas se llegó a esa «pubertad» literaria?

\section{Contra/reflexión}

Necesitábamos un tablado sólido en el que poder apoyar pie para culminar la truncada danza de las vanguardias dominicanas, para cerrar de alguna manera el círculo de nuestra indagación. Los puntos de reflexión antes expuestos nos proporcionaban el escenario, y nos llevaban de la mano hacia el autor que -como uno de esos «solitarios solidarios» de los que habla Octavio Paz en Los hijos del limo ${ }^{22}$ - encarnaba como por milagro y de una manera polifónica la «decantación» (cf. Guillermo de Torre) y la «exploración» (cf. Octavio Paz) más audaz dentro de las letras domjnicanas. Nos estamos refiriendo a Manuel del Cabral (n. 1907), de quien entonaran hondas alabanzas Gerardo Diego («primer gran poeta analfabeto que conozco») o Gabriela Mistral («es uno de los pocos poetas del postmodernismo que es dueño de un múltiple y poderoso registro lírico. 'Su poesía' no puede encasillarse») ${ }^{23}$. Es curioso, y digno de un delicado estudio de sociología e intrahistoria literaria, considerar que en ningún análisis, panorama o bibliografía sobre la vanguardia dominicana se incluye el nombre de Cabral, generalmente despachado con epítetos como «inmenso», «torrencial» o - es el caso de Anderson Imbert- como «desorbitado" (a ello dará el poeta cumplida respuesta en su autobiografía ${ }^{24}$ ). Es aún más curioso constatar que los críticos tienden a soslayar su obra en prosa, o a mencionarla como pasando de puntillas por ella, mientras que

21 Guillermo de Torre, op. cit., pág. 30.

22 «a poesía de la postvanguardia (no sé si haya que resignarse a este nombre no muy exacto que empiezan a darnos algunos críticos) nació como una rebelión silenciosa de hombres aislados» o «solitarios solidarios», como describe en el párrafo anterior a Albert Camus (op. cit, pág. 210).

23 Juicios recogidos por el propio Cabral en su irregular y fascinante autobiografía Historia de mi voz (Santiago de Chile: Editorial Andes, 1964), págs. 129 y 153-154 respectivamente.

27 «(...) 'desorbitados' fueron Whitman, Hugo, Blake, Rimbaud, Herrera y Reissig, Vallejo, Huidobro, etc, y son Ezra Pound, Neruda, y otros que tú sabes..., que sabe tu silencio, tu ilustre silencio» (Historia de mi voz, pág. 110 ). 
se demoran un poco más en una de sus múltiples voces, la de la «poesía negra». La prosa de Manuel del Cabral merece una profunda reivindicación primero y un exhaustivo análisis, después, pues es de una complejidad y densidad fascinantes, a la par que polifónica y polimórfica, rica en variaciones sobre un mismo tema y en «agujeros» por los que asomarnos a esa «realidad otra» que tanto habrá de fascinar luego a narradores como Cortázar o García Márquez, por citar a dos muy señalados.

Pero retornemos a la «contra/reflexión» que nos llevó de la mano hacia Manuel del Cabral. Y hagámoslo partiendo de los puntos que nos sirvieron de reflexión previamente:

A.- ¿Era posible el desarrollo de la vanguardia en un país «transido de ruralidad»? Unas poderosas líneas de Gabriela Mistral sobre la poesía de Pedro Salinas arrojaban luz sobre el enigma:

Sí que tiene y muestra 'Pedro Salinas' sensibilidad nueva -nueva, no de última hora, cosa diferente. Sólo que para ser 1928, él no hace derroche de aviones, ni de T.S.H., ni de grúas. Sensibilidad nueva significa mirada inédita, pero que cae sobre las cosas con que nos codeamos, sea huerto o majada. Me hacen sonreír algunos libros que llegan de rincones ruralísimos de América: están atravesados, están veteados de fabrilismo, de maquinismo, de Torre Eiffel, de Picassos y Paul Morands, y han sido fabricados mientras se oía la rumia búdica de las vacas o el cordón lacio del agua de riego. Muy legítima manufactura futurista la que sale de Brooklyn o de Montparnasse o de Berlín. Pero, «iqué tenemos que hacer nosotros en medio de esas vastas hierbas y esos ríos sin captación de usina alguna que son los nuestros con el fordismo y citroneísmo poéticos? ${ }^{25}$ (subrayados míos).

O lo que es lo mismo, y parafraseando al Cortázar que teoriza sobre el cuento fantástico en «Del cuento breve y sus alrededores» (en Ultimo round): la auténtica literatura de vanguardia no consiste en un gran despliegue de «cotillón» futurista, de metrópolis y máquinas y rascacielos, de automóviles a velocidades vertiginosas, de fábricas y engranajes y vertederos urbanos. La auténtica literatura de vanguardia consiste en ver lo que nos rodea con ojos nuevos, en dar vida nueva, nuevos enfoques, a lo que tenemos más cercano. Y esto vale tanto para el rascacielos como para el bohío. En una dicotomía campo/ciudad que también aparece en los cuentos de Vigil Díaz, y que es recurrente en la prosa de

25 Originalmente publicado en Repertorio Americano (San José de Costa Rica), en 1928 , es citado por Juan Loveluck en «Neruda y la prosa vanguardista» (recogido en Fernado Burgos, op. cit., págs. 125-135). 
las vanguardias ${ }^{26}$, Cabral nos narra su llegada, coetánea a la de su paisano Juan Bosch, a la capital dominicana ( «la más grande ciudad que por primera vez conocían nuestros ojos rurales»), como una historia de hostilidad entre miradas ( «estábamos inofensivos ante la navaja de los ojos capitaleños»), pues «ni a Juan 'Bosch' ni a mí nos perdonaban los capitaleños (y menos la tiranía 'de Trujillo') el exceso de luz ingenua que traíamos de la provincia» 27 (mi subrayado). Esa mirada rural, esos ojos de luz ingenua, conforman la «mirada inédita» que vindica Gabriela Mistral como creadora de una sensibilidad nueva, y jalonan toda la obra en prosa de Manuel del Cabral de una manera casi obsesiva, cobrando vida propia, evocándonos en infinidad de ocasiones las experiencias salvajemente hermosas y salvajemente surrealistas de Dalí ${ }^{28}$ y de Buñuel, dos nombres que son muy afines a la obra del escritor dominicano ${ }^{29}$ :

De repente, siento que Chinchina no está en mis manos; me arranco los ojos, los echo al gentío, se cuelan por todas partes, se pegan, agujerean $[\ldots]$ Los ojos de Chinchina lo caminan, lo lamen y, a ratos, corren, huyen de sus dedos sucios 'los de 'Piedra el cieguito'" (Chinchina, págs. 68-69).

[...] lucho con los ojos que me esperan en las esquinas y detrás de las manos (Chinchina, pág. 55).

Obsesión por los ojos, obsesión por la mirada, que ha de ser nueva, que es nueva en las prosas de Cabral, tal esa «visión más allá de la retina» de la que hablaba Ramón Gómez de la Serna cuando se refería a su amigo el pintor y escritor Solana. En palabras del propio autor dominicano:

[... mi temperamento rebasa los límites de la vida doméstica; tal vez por mi extraña inclinación a no ver simplemente lo que el

\footnotetext{
26 «Las metáforas nacen, con sorprendente unanimidad, de la oposición ciudadcampo. Quizá sea por esto. por el gusto a los extremos, tan típicamente vanguardista. Quizá por influencia de Góngora, que tanto gustaba de estas paradojas, al establecer las relaciones ciudad-campo y campo-mar en Soledades. Quizá, finalmente, porque la nueva realidad ciudadana, aunque tan diferente a la campestre se mostraba como una parodia, a veces grotesca, de ésta». (Buckley y Crispin, op. cit., págs. 177-178).

${ }^{27}$ Historia de mi voz, pág. 50.

${ }^{28}$ Dalí escribe en «La liberación de los dedos» (1929): «Un solo dedo ha sido el tema de algunas de mis pinturas y realizaciones fotográficas recientes..., el camino violento por el cual podemos someter aún las cosas a su propia de libertad...” (recogido por Buckley y Crispin, op. cit., pág.352). Esa liberación de los miembros (ojos, manos, pies) es recurrente en toda la obra de Cabral, y se hace especialmente significativa en Chinchina busca el tiempo (editada por vez primera en Santo Domingo en 1940).

${ }^{29}$ Consultar anexo bibliográfico de las obras de Manuel del Cabral analizadas en la elaboración de este trabajo.
} 
ojo físico ve, me desligaba un poco de los sucesos o prejuicios de la pequeña geografía en que vivía [...] (Historia de mi voz, págs. 58-59).

La mirada del artista trasciende las geografías, campo o ciudad. Esa es la verdad de las vanguardias.

B.- A la segunda cuestión que nos planteábamos -el internacionalismo de las vanguardias, la transgresión de fronteras geográficas- ya hemos respondido en parte con las notas precedentes. Sin embargo, este aspecto es de sumo interés, y vital para entender (o no entender) la vanguardia hispanoamericana. Un primitivista fragmento de la autobiografía de Manuel del Cabral nos servirá para matizar nuestra «contra/reflexión». En él nos narra una breve visita a Haití que incluyó una excursión a un remoto poblado para «conocer personalmente a los zombíes (sic)». He aquí la ilustrativa anécdota del regreso:

Cuando volvimos rumbo a la capital haitiana, por la carretera que conduce a Puerto Príncipe, a intervalos veíamos bajo los frondosos árboles, a ambos lados de la ruta, entre piedras y hojas, a nativos que fornicaban, y a veces, bajo los mismos árboles, a otros haitianos desnudos, que al agacharse para hacer sus necesidades biológicas parecían que estaban en tres patas... La abundancia de su sexo masculino es el único don del cielo que les ha dado Ia tierra, pero ellos dicen que la riqueza que se desborda por sus ingles es también la desgracia de su pueblo, porque ya casi tienen más gente que tierra; el amor, si no los mata de placer, los mata de hambre. Así, pues, como no pueden dejar una maña tan vital y tan sabrosa, y como no quieren usar el progreso de un eunuco calabozo de caucho para su dedo mayor..., porque esa paja civilizada, según ellos, les quita su prestigio de carne viva, sólo les quedan dos alternativas: o emigran en masa a países despoblados, o esterilizan el bien tan desgraciado que les cuelga orgulloso entre las piemas.

Es que lo que París cotiza a muv buen precio, en Haití no se vendc (Historia de mi voz, pág. 29; subrayado mío).

En clave de humor, y con característica greguería bufa (preservativo = «eunuco calabozo de caucho para 'el' dedo mayor, (...) paja civilizada»), Cabral enfrenta a dos mundos, dos visiones, dos culturas y, por qué no, dos líneas diferentes en la vanguardia: la que viene de Europa (París/paja civilizada) y la que viene de América (Haití/prestigio de carne viva). Las raíces del vanguardismo en la República Dominicana, como las del resto de los países antillanos, hay que buscarlas en ese «barro» autóctono que ensalzaron los postumistas, hecho sin duda «carne viva» en las manos de Cabral (los ecos bíblicos son continuos tanto en su obra como en la de Moreno Jimenes). Frente al 
rugido monocorde de motores del «fordismo» y del «citroneísmo» de que nos hablaba Gabriela Mistral, las voces y los ritmos de los negros; frente al hombre-máquina, hombre-masa, hombre-engranaje de otras latitudes, el zombie haitiano; frente a la alienación del individuo ante un paisaje de hormigón, el hombre que poco a poco se hace selva, regresa a su semilla, se torna un recién nacido (figura recurrente tanto en Cabral como en Moreno Jimenes). Así, en Cabral cobran pleno sentido las palabras que aparecían al comienzo del Manifiesto postumista: «La América debe superar a la Europa». No en vano, en su sola figura confluyen y se «decantan» todas las sangres que habían iniciado el cambio en la República Dominicana. Liberando sus ojos rurales, construyó una nueva visión. Liberando sus manos ( «mis manos siguen soltando pájaros») ${ }^{30}$, modeló incansablemente las arcillas autóctonas que los postumistas tan sólo habían alcanzado a reivindicar, e hizo realidad la rotunda afirmación de Moreno Jiménes: «En cualquier sitio de la tierra en que nos hallemos estamos en el centro del universo; se puede ser dominicano y ser universal; es más, los más despabilados en su ambiente connatural son los más universales» («Tertulia en mis viajes», pág. 26 , inserto en el número de El día estético que recoge el breve poema en prosa «Burbujas en el vaso de una vida breve»).

C.-- Las letras dominicanas alcanzan no sólo la pubertad, sino también la adolescencia mágica y descubridora de manos de Manuel del Cabral. Es por ello que se llenan con él de prosas iniciáticas, surrealistas, metafísicas, existencialistas, fantásticas, aforísticas, telúricas ${ }^{31}$. Y, engastadas en la escritura como minas que van estallando a nuestros ojos, decenas de hermosas y originales greguerías cruzan las dudosas fronteras entre la prosa y el verso.

40 Chinchina busca el tiempo, pág. 27. La liberación de la mano, que tanto juego ha dado dentro de la literatura fantástica, es de clara raigambre surrealista (cf. Dalí), y se erige también en otro de los múltiples motivos recurrentes en la prosa de Manuel del Cabral. Dentro de la vena más puramente fantástica, es interesante en este aspecto el relato «Galo» (en 20 cuentos, págs. 94 a 97). Se trata de un cuento breve cargado de minas oníricas en el que las manos del protagonista, Galo, se le desprenden en la noche y cometen todo tipo de crímenes a las órdenes de Simón, un mago hindú.

.31 Es sugerente el texto que aparece en la solapa de la portada de 30 parábolas (Buenos Aires: Editorial Lucania, 1956):

«La prosa de Cabral, desorganizada a veces pero siempre medular, tiene la misma raíz telúrica de los cuentos de Horacio Quiroga; talento generoso que se desborda en sangre y no en cáliculo literario, como -finalicen valiendo las comparaciones- Jorge Luis Borges. Así, en oposición a cierta crítica, en esta prosa tan original de Cabral, no hay posibles puntos de contacto ni con las parábolas de Oscar Wilde ni con los cuentos de Poe o de Kafka. Aunque Cabral, si coincide con ellos, es en lo poco común de su voz y en la jerarquía de su creación". 


\section{INTERLUDIO: CIELO Y TIERRA, O EL MISTICISMO DE DOMINGO MORENO JIMENES}

Sería injusto soslayar la figura de Domingo Moreno Jimenes en nuestra visión panorámica de la vanguardia dominicana, y más si tenemos en cuenta que también intentó expresar sus tentativas renovadoras en prosa. En la contraportada de su interesante opúsculo, publicado en 1948 (ver nota 7), Burbujas en el vaso de una vida breve, que es un texto elegíaco ante la tumba de la madre de un amigo, se plantea ya los límites entre verso y prosa como «un problema» de comunicación con el lector:

[...] si yo me revelaba por igual en la una o la otra manera, „por qué estos distanciamientos que ponen complejidad en acto tan simple? Tenderle a la poesía un vistuario de prosa, no parecería lo más conveniente? (sic). Así la comunicación sería más íntima y lograríamos aislarnos de tantos seres por muchos motivos ajenos a la función poética.

Asimismo, el escribir en prosa supone explícitamente un reto:

La primera copia se hizo en mi primigenio verso libre habitual; pero yo después hice que lo pusiera en prosa como un desafío real a las formas y para que la revolución no se quedara en un vano forcejeo de ritmos, sino que fuera integral y antológica, como los elementos: la tierra, el agua, el viento, la vida. Cortando el nudo gordiano entre la prosa y el verso, así la acción de América tendría una verdadera renumeración y los cinco siglos incompletos, de nadería, de vacuidad y de ensayos fortuitos se resolverían en la realidad del verbo, que nació a la vida primero que el mundo y vino a la tierra primero que el hombre (pág. 7).

Su alusión final al «verbo» no es ociosa, tiene un contenido bíblico y filosófico que el resto de su breve escrito no hará sino reiterar y matizar (en sus notas finales, «Postreros caminos del postumismo», Moreno Jimenes escribe: «la obra de la reencamación del verbo debe ser producto de la gracia poética si es que queremos que Dios vuelva a hablar en nosotros», pág. 28). Este destacar los valores creativos, inmanentistas y ordenadores del verbo, de la palabra, en suma, es de raíces no tan solo cristianas, sino también clásicas: los estoicos consideraban al «logos» como principio ordenador del universo ${ }^{32}$. Todo ello se encuentra claramente

.32 Dice The Oxford Companio to the Bible (págs. 463-464): «In the Hebrew Bible, the word of God is both creative (...) and commanding. (...) In Greek, "logos' meant both spoken word and pervading principle. Stoic philosophy (...) saw the 'logos' as the ordering principle of the universe; the wise person aims to live in harmony with it». 
ímplicito en dos revistas clave de la vanguardia cubana, Verbum y Origenes ${ }^{33}, \mathrm{y}$ abre camino a futuras indagaciones sobre los contactos entre la vanguardia cubana y la dominicana (los estudios al uso tienden a hermanar a esta última con la puertorriqueña, soslayando lo cubano). Moreno Jimenes quiere partir de él para estructurar su religión americana («yo fui un religioso de América», pág. 5), que postulaba que había que crear lo nuevo con lo eterno, en un juego de paradojas y oxímoron («la inexistencia de la existencia», pág. 13; «su severidad era alegre y su alegría muy triste», pág. 13; «[...] vivir muriendo para que todos ignoren que la muerte es la vida!», pág. 16; «su lejanía, hecha de montaña y de sopor de sima; compendio de barro y de nube; de azul y de noche; de aurora y de crepúsculo; de luz y de tinieblas», pág. 17) que, junto a los muy recurrentes conceptos de «lo eterno», «el silencio» y «la soledad», nos evocan a los místicos y también nos llevan al principio ordenador de las vanguardias: ir de lo inefable a lo «ablable», expresar lo inefable con imágenes poderosas y nuevas, como recién nacidas. $Y$ es aquí donde estriba la diferencia entre lo alcanzado por Moreno Jimenes y los logros del culminador de la vanguardia dominicana, Manuel del Cabral: el primero se tiene que conformar con hablar de lo inexplicable en conceptos abstractos (no explora, se limita a perfilar los mapas del misterio); el segundo dibuja en sus versos y en sus prosas esos principios etemos (vida y muerte, inocencia y corrupción, ángeles buenos y malos ${ }^{34}$ ) del universo.

\section{CULMINACIÓN: MANUEL DEL CABRAL CONQUISTA LOS ELEMENTOS}

Con Manuel del Cabral, y como ya hemos venido apuntando durante estas líneas, concluimos nuestra indagación sobre las vanguardias

${ }^{3.3}$ Escribe Müller-Bergh (op. cit., págs. 62-63) en su brevísimo análisis de la vanguardia en Cuba: «El vínculo de continuidad de sentido entre Verbum y Origenes queda evidente, si tenemos en cuenta que el vocablo forma parte del evangelio de San Juan 1, 1- [4, uno de los más herméticos y hermosos de la liturgia católica, que empieza de la siguiente manera: 'In principio erat Verbum et Verbum erat apud Deum et Deus erat Verbum. Hoc erat in principio apud Deum...'. Es decir, esta oración que incluye el ritual de la misa, une la obsesión por el origen del lenguaje, característica del pensamiento lezamesco, y una concepción espiritual, vital, de raíz católica, también evidente en la palabra 'Orígenes'».

3.4 Apuntamos aquí un poco a vuelapluma, aunque merecerían un estudio más amplio, los puntos de contacto entre Sobre los angeles de Alberti (1929) -y especialmente el fascinante poema «Deshaucio»- y parte de la obra en prosa de Cabral, muy particularmente Chinchina busca el tiempo, en la que el motivo del hombre deshabitándose («Ahora, yo no quisiera tocar con la mano mi ropa que trasciende hoy a cosa que está lejos del hombre» o « ¿Estaré yo aquí...conmigo?», págs. 26 y 32) y el de los ángeles («viene de no sé dónde, de no sé qué desequilibrio, de no sé qué sanatorio de ángeles», pág. 28) son muy recurrentes. 
dominicanas en prosa. Lo mismo que García Márquez se reencontró con un Maigret eternamente en busca de un triste criminal, así nosotros hemos pretendido revivir la también eterna búsqueda de esa «realidad otra» por parte del escritor dominicano. Manuel del Cabral es culminación de las vanguardias dominicanas porque supone su más pura y brillante decantación artística, su más fecunda exploración del mundo. Es también culminación porque cierra un ciclo vital de conquista de la realidad en todas sus facetas que iniciaron los postumistas con su pretendida conquista de la tierra, de los barros autóctonos; que enriqueció Vigil Díaz lanzándose a los cjelos en acrobacias azules, en 'looping the loop'; que ahondó Moreno Jimenes partiendo de las arcillas postumistas para, a través de la palabra, del «logos» griego y bíblico, unir el principio con el fin en un todo, enlazar el cielo con la tierra, la vida con la muerte. Manuel del Cabral, en sus prosas, será tierra, su tierra dominicana, en ojos nuevos, primigenios, eternos:

Sus grandes ojos 'los de las vacas' inauguran la tierra (Chinchina, pág. 65).

Será también cielo azul («azul sin geografía», Chinchina, pág. 72), cielo explorado, cielo conquistado desde la tierra, como las cometas que se pierden en lo alto, las «cometas con algo» (Chinchina, pág. 46).

Yá sé por qué, a pesar de que estoy ya tan viejo, veo entre las nubes unos caros pantalones míos. ¿Ves aquel rabo de dril blanco, tan coqueto en aquella cometa?

¿Hoy, Chinchina, sueño tanto... que hasta mi ropa se va sola al cielo!

Será por último -nueva conquista- agua, de océanos y de lluvias, de lagunas y de charcos: la evocación, implícita o explícita, del elemento agua es, de hecho, dominante en Chinchina busca el tiempo, uno de cuyos epígrafes se titula, significativamente, «Agua siempre». Cabral reflexiona acerca de la inocencia y de la pureza de las aguas y de esa maravillosa niña/agua que es Chinchina:

Ya ves, Chinchina, todavía queda agua, mucha agua .... ¡agua grande! (Chinchina, pág. 38).

Los siete años de Chinchina se desnudan para vestirse de río (...) Los siete años de Chinchina se desnudan para vestirse de líquido. Sin embargo, como Chinchina es de agua, yo la miraba, pero no la veía ... (Chinchina, págs.25 26).

Finalmente, Cabral consigue en su prosa una asombrosa síntesis de todos los elementos, del cielo, la tierra, el agua: una visión completa e 
La conquista de los elementos: evolución de la vanguardia dominicana... 201

innovadora de la realidad a través de esa su mirada inédita y de su voz polifónica. Cerramos estas notas con un memorable fragmento de Chinchina busca el tiempo que es, en su pequeñez casi infantil, una enorme cosmovisión:

\section{ZAPATOS VIEJOS}

Con dos agujeros como dos ojos que amanecieron sin dormir, los zapatos empapados y a la orilla del camino miraban hacia arriba, tal vez. pensando que por fin ha dejado de caer cielo sobre las montañas, allá, de donde ellos bajaron amasando barro y haciendo huellas hondas...

Estaban sin gente. Alguien los puso allí para que su pequeña cantidad de río se calentara y volviera al azul con la subida del amanecer. No son los del Cura, porque la mina de la Muerte siempre le tiene muchos pares... siempre lo tiene satisfecho; tampoco los de Guaco el labrador, porque aunque están agujereađos, los usa sólo los domingos, además, para Guaco todavía están nuevos...

Ya ves, Chinchina, estos mojados zapatos viejos no son del hombre; no han inventado nada; no dicen nada, no pertenecen ni al dolor ni a la alegría; están ahí sin historia, como dos cosas más sobre la tierra. Ah, pero en uno de sus pocitos bebe un canario, se lava bien la garganta y le hace un discurso al día... (págs. 43-44)

Prosa de decantación de muchas de las esencias vanguardistas: el humor, la fina ironía social, el súbito resucitar de una naturaleza muerta, la infinitud de los objetos más insignificantes, todo un mundo hecho ojos creadores, ojos voladores, ojos/agujeros hacia otras realidades intuidas: más allá de los cielos, de las aguas y de la tierra ${ }^{35}$.

\section{EDICIONES CONSULTADAS DE LA OBRA DE MANUEL DEL CABRAL}

- Chinchina busca el tiempo. Buenos Aires: Editorial Huemul, 1966 (4ª edición, la $I^{a}$ fue en Santo Domingo en 1940). Incluye introducción, notas y vocabulario de Marta Elena Groussac de Rego.

- 20 cuentos de Manuel del Cabral. Buenos Aires: s.e., 1951. Seleccionados por Miguel Román Pérez (hijo). Ejemplar con dedicatoria autógrafa a Eugenio D'Ors.

35 Insistimos una vez más en lo compleja y fascinante que es la obra en prosa de Manuel del Cabral. Chinchina, los cuentos, su autobiografía y los aforismos de Los relámpagos lentos merecen estudios tanto de conjunto como particulares, pues la diversidad de enfoques que sugieren es enorme. Ën lo que precede, dado el alcance limitado de un estudio panorámico, hemos pretendido dejar tan sólo chispazos, lanzar retos a futuros y necesarios análisis de las prosas de Cabral. 
- Historia de mi voz. Santiago de Chile: Ediciones Andes, 1966. Ejemplar también dedicado autógrafamente por Manuel del Cabral a Pedro Salvador de Vicente, y firmada en la «Embajada Dominicana. Holanda 60. Santiago de Chile».

-- Los relámpagos lentos. Buenos Aires: Editorial Sudamericana, 1966. Incluye todos los relatos de Cabral que habían ido apareciendo diseminados aquí y allá.

- Poemas de amor y sexo. Buenos Aires: Ediciones de la Flor, 1974. Antología de textos poéticos elaborada por el propio Cabral que incluye dos interesantes relatos: «Complementario» y «Los burros sagrados».

Francisco José Gómez PÉrEZ Universidad Complutense de Madrid 